\title{
Nectar and pollen production in ornamental cultivars of Prunus serrulata (Rosaceae)
}

\author{
Monika Strzalkowska-Abramek \\ Departament of Botany and Plant Physiology, Subdepartment of Plant Biology \\ University of Life Science in Lublin, 15 Akademicka St., 20-950 Lublin, Poland
}

\begin{abstract}
Planting ornamental species can help to create pollinator-friendly habitats. In the present study the flowering phenology and floral reward (nectar and pollen) in two cultivars of Prunus serrulata ('Kanzan' and 'Amanogawa') were evaluated in 2014-2015 in the city of Lublin (south-east Poland). On average, the onset of flowering of P. serrulata occurred in the first ten days of April ('Kanzan') or at the end of April ('Amanogawa'), and lasted 8-17 days. In each year of the study, P. serrulata 'Kanzan' started flowering 11-18 days earlier than P. serrulata 'Amanogawa'. The double flowers of $P$. serrulata 'Kanzan' offered only tiny amounts of nectar and pollen. The total mass of sugars was $0.59 \mathrm{mg}$ per flower and that of pollen $0.08 \mathrm{mg}$ per flower. The semi-double flowers of P. serrulata 'Amanogawa' produced $4.5 \mathrm{mg}$ of sugars per flower and $0.17 \mathrm{mg}$ of pollen per flower. The frequency of pollinator visits to flowers was low in P. serrulata 'Amanogawa' and very low in P. serrulata 'Kanzan'. Therefore, if pollinator-friendly arrangements are made in urban areas, these cultivars should not be planted.
\end{abstract}

Key words: floral reward, food for pollinators, insect visitors, ornamental plants, urban areas

\section{INTRODUCTION}

Pollinator decline is currently a global issue (Goulson et al., 2015; Rhodes, 2018). Lack of pollinators is reported to impair agricultural and horticultural production (Gallai et al., 2009) as well as ecosystem stability (Vanbergen et al., 2013). Although specific causes of pollinator decline are not always obvious, the lack of food resources is indicated as a critical factor for the reduction in the abundance of pollinating insects (Alaux et al., 2010; Filipiak et al., 2017; Jachuła et al., 2018c; Rhodes, 2018). There are several possibilities for increasing pollinator biodiversity and abundance, e.g. the restoration and/or improvement of beefriendly habitats 'bee pastures') in agricultural and urban areas (Wrzesień et al., 2016b, 2016a; Jachuła et al., 2018a; Ziaja et al., 2018). In particular, an increase in nesting sites and introduction of food plants is required (Somme et al., 2016). Among the initiatives, an improvement of floral bee forage in urban areas is highly recommended (Matteson and Langellotto, 2011; Hicks et al., 2016; Somme et al., 2016). In establishing bee-friendly gardens, the knowledge on nectar and pollen quantity and quality as well as the information if a floral reward is attractive to pollinators are required (Denisow et al., 2014a; Garbuzov and Ratnieks, 2014; StrzałkowskaAbramek et al., 2016a; Jachuła et al., 2018b).

Many current studies have indicated that nectar and pollen traits are crucial for the foraging behaviour of pollinators (Abou-Shaara, 2014; Antoń and Denisow, 2014). Nectar is produced by nectary glands. It is an aqueous solution of sugars (mainly sucrose, glucose, and fructose), with some 
additions of other organic compounds (amino acids, proteins) (Nicolson and Thornburg, 2007; Antoń et al., 2017). As a major energetic food for pollinators, nectar plays an important ecological role in establishing plant-insect interactions (Strzałkowska-Abramek et al., 2016b, 2018; Nepi et al., 2018). Nectar traits (volume, sugar proportion, sugar concentration) vary considerably between species (Bożek et al., 2015; Strzałkowska-Abramek et al., 2018). Also environmental conditions impact considerably on nectar production and the sugar concentration (Petanidou and Smets, 1996; Nicolson and Thornburg, 2007; Denisow et al., 2016). Pollen is also an important food resource for pollinators (Di Pasquale et al., 2013; Antoń and Denisow, 2018). It is the most important source of proteins and other nutrients (vitamins, lipids, hormones); therefore, pollen diet has a major impact on pollinators' health, their growth, development, and immune response (Alaux et al., 2010; Brodschneider and Crailsheim, 2010; Filipiak, 2018).

The ornamental horticulture trade is increasing due to the enlargement of production and, consequently, ornamental plants receiving a great deal of attention (Horticulture Statistics, 2017). Planting ornamental species can help to create habitats for pollinators in urban parks, home gardens, yards, rooftop and container gardens, as well as on small patios, and balconies (Denisow et al., 2014b; Garbuzov and Ratnieks, 2014).

The genus Prunus contains more than 200 species of trees and shrubs, some of which are widely used in urban arrangements due to showy flowers and attractive foliage colours (Kato et al., 2012). In Central Europe, Prunus species are indicated as important spring melliferous plants (Farkas and Zajácz, 2007). In Northern Hemisphere, Prunus serrulata (Japanese Flowering Cherry) is very popular because of its mass floral display in the spring (Chung et al., 2011).

The aim of the present study was to establish the duration of flowering of two cultivars of Prunus serrulata recommended for growing in urban areas. The quantity of nectar and pollen was evaluated. In addition, it was determined if the floral reward was attractive to insect visitors.

\section{MATERIAL AND METHODS}

\section{Study sites and plant species}

The study was carried out in 2014-2015 in the city of Lublin located in the Lublin Upland, SE (south-west) Poland $\left(51^{\circ} 08^{\prime}-51^{\circ} 18^{\prime} \mathrm{N}\right.$ and $21^{\circ} 27^{\prime}$ - $21^{\circ} 41^{\prime} \mathrm{E}$; elevation: $\left.170-220 \mathrm{~m}\right)$. Lublin is the largest city of south-eastern Poland, with specific flora characteristic of cities with the so-called atmospheric urban heat island (UHI) (Rysiak and Czarnecka, 2018).

Prunus serrulata Lindl. (Rosaceae) is native to East Asia (Kato et al., 2012). In Europe, P. serrulata 'Kanzan' and P. serrulata 'Amanogawa' are recommended for landscape architecture and gardening arrangements due to their showy flowers. Therefore, these cultivars were selected for the study.

$P$. serrulata 'Kanzan' is a medium-sized deciduous tree, whose flowers are light pink and double. $P$. serrulata 'Amanogawa' develops a columnar crown; the flowers are deep pink, semi-double. The plants of both cultivars require full sun; however, they will grow well enough in shade.

\section{Observations of flowering}

Each year of the study, the phenology of flowering was monitored and the onset (= beginning; $10 \%$ of inflorescences per individuals in bloom), peak (= full bloom; approx. 50\% of flowers in bloom), and the end ( $=$ termination; $80 \%$ of flowers completed flowering) were assessed (Denisow et al., 2014a). The observations were conducted every two days, on four trees, randomly selected each year. Simultaneously with the phenological observations, flower life-span ( $\mathrm{n}=15$ flowers for each cultivar and growing season), defined as the period of time between bud opening and corolla wilting, was determined.

For each tree, the number of shoots and the number of flowers per shoot $(n=20$ shoots) were established. The average number of flowers per tree was calculated by multiplying the number of flowers per shoot by the number of shoots per tree.

\section{Nectar production}

In Prunus species, the nectaries are located in the receptacle (Farkas and Zajácz, 2007). Nectar production was assessed using micropipettes (Antoń and Denisow, 2014). Samples of nectar $(\mathrm{n}=5$ samples per cultivar and growing season) from previously bagged flowers were collected on the third day of the flower life-span. To exclude insect visits, tulle isolators were fitted. Each sample contained nectar extracted from 10 to 30 flowers. The nectar was withdrawn four or five times during each growing season. Sugar concentration in the nectar was measured with an Abbe refractometer (RL-4 PZO, Warszawa Poland). The total mass of 
sugars secreted in the nectar was calculated per flower (mg) and per tree (g).

\section{Pollen production}

Pollen production was evaluated using the etherethanol method (Strzałkowska-Abramek et al., 2016b). Unopened anthers from buds were collected in weighed glass containers ( $\mathrm{n}=4 \times 100$ anthers). Then, the anthers were placed in a dryer (ELCON CL 65 , Poland) at approx. $33^{\circ} \mathrm{C}$. The pollen was rinsed from the anthers once with pure ether (1-2 $\mathrm{ml}$ ) and then 5-7 times with 70\% ethanol (approx. $20 \mathrm{ml}$ ). The mass of produced pollen was assessed per flower (mg) and per tree (g).

\section{Insect visitors}

Insect activity was recorded simultaneously with the observations of flowering. The observations were conducted for three days for each cultivar. Insects foraging at 9.00, 12.00, 14.00 and $16.00 \mathrm{~h}$ $(\mathrm{GMT}+2.00 \mathrm{~h})$ were noted. The total number of visiting insects was recorded at each time point.

\section{Data analysis}

Data are presented as means with standard deviation $( \pm$ SD). Data for different cultivars and years of study were analyzed using one-way ANOVA. Posthoc comparison of means was made with Tukey's multiple comparisons test. The Statistica software (ver. 6, Statsoft, Poland) was used.

\section{RESULTS}

\section{Flowering phenology and abundance}

On average, $P$. serrulata 'Kanzan' bloomed from mid-April till the end of April, while P. serrulata 'Amanogawa' bloomed from the end of April till mid-May (Fig. 1). In 2014, the flowering started
7-14 days earlier than in 2015. In each year of the study, P. serrulata 'Kanzan' started flowering 1118 days earlier than $P$. serrulata 'Amanogawa'. The flower life-span ranged from 2.5 to 5.3 days (mean $=3.6$ days). The process of flower opening was most intensive in the morning/midday hours; between 9.00 and $12.00 \mathrm{GMT}+2 \mathrm{~h}$ approximately $70 \%$ of flowers were opened.

The cultivars studied developed a similar number of flowers per tree. However, year effect was established for the number of flowers $\left(F_{1,6}=8.74\right.$ $p=0.003$ for $P$. serrulata 'Kanzan'; $F_{1,6}=7.84$, $p=0.003$ for $P$. serrulata 'Amanogawa'). In both cultivars, significantly more flowers (2-3-fold) were noted in 2014, compared to 2015 (means for 2014 vs $2015=63,450$ vs 19,630 for $P$. serrulata 'Kanzan'and 66,750 vs 29,320 for $P$. serrulata 'Amanogawa').

\section{Nectar and pollen rewards}

The amount of nectar produced was approx. three times as high in $P$. serrulata 'Amanogawa' as in P. serrulata 'Kanzan' $\left(F_{1,18}=7.559, p=0.014\right)$ (Tab. 1). For each cultivar, year-to-year disparity in the amount of secreted nectar was also recorded $\left(F_{1,18}=7.44, p=0.004\right)$. On average, the sugar concentration of nectar was similar in both cultivars. However, for both cultivars, the sugar concentration was lower in 2014. The nectar sugar mass produced per flower varied between the cultivars $\left(F_{1,18}=\right.$ $12.519, p=0.003)$ and years of the study $\left(F_{1,18}=\right.$ $4.752, p=0.034)$. The mass of sugars per flower was $0.59 \mathrm{mg}$ in $P$. serrulata 'Kanzan', on average, and was $75-93 \%$ lower than in $P$. serrulata 'Amanogawa'. A single tree of $P$. serrulata 'Amanogawa' produced approx. six times more sugars, compared to P. serrulata 'Kanzan'.

\section{Prunus serrulata 'Amanogawa'}

2014

2015

Prunus serrulata 'Kanzan'

2014

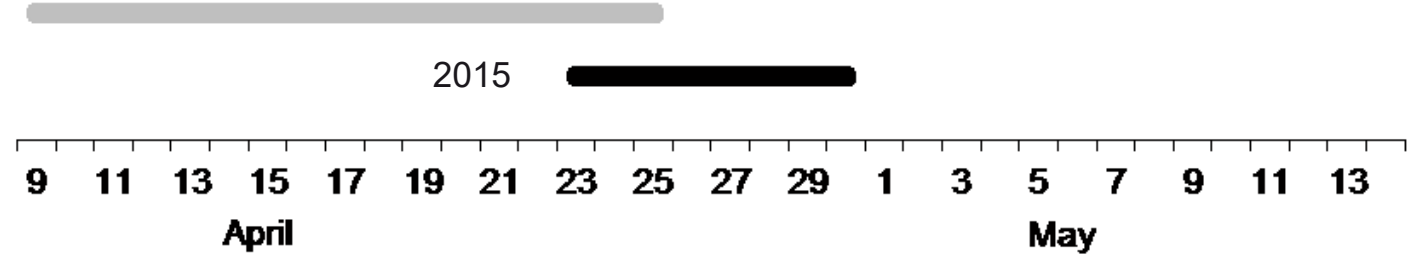

Figure 1. Flowering phenology of two cultivars of Prunus serrulata in 2014-2015, Lublin, SE Poland 
Table 1. Nectar production, sugar concentration and sugar mass in two cultivars of Prunus serrulata in 2014-2015, in Lublin (SE Poland). Means \pm SD (standard deviation) are given. Means with the same lower-case letter do not differ significantly between the growing seasons within cultivar, whereas means with the same capital letter do not differ significantly between cultivars at $p=0.05$, based on Tukey's HSD test

\begin{tabular}{lccccc}
\hline Cultivar & Year & $\begin{array}{c}\text { Nectar amount } \\
\text { per flower } \\
(\mathrm{mg})\end{array}$ & $\begin{array}{c}\text { Sugar } \\
\text { concentration } \\
(\% \mathrm{w} / \mathrm{w})\end{array}$ & $\begin{array}{c}\text { Sugar amount } \\
\text { per flower } \\
(\mathrm{mg})\end{array}$ & $\begin{array}{c}\text { Sugar amount } \\
\text { per tree } \\
(\mathrm{g})\end{array}$ \\
\hline \multirow{3}{*}{ Kanzan } & 2014 & $1.61 \mathrm{~b} \pm 0.41$ & $49.8 \mathrm{a} \pm 12.3$ & $0.81 \mathrm{~b} \pm 0.38$ & $51.03 \mathrm{~b} \pm 22.36$ \\
& 2015 & $0.53 \mathrm{a} \pm 0.12$ & $72.3 \mathrm{~b} \pm 9.1$ & $0.38 \mathrm{a} \pm 0.12$ & $6.65 \mathrm{a} \pm 2.64$ \\
\hline \multirow{3}{*}{ Amanogawa } & mean & $1.07 \mathrm{~A} \pm 0.86$ & $51.1 \mathrm{~A} \pm 10.5$ & $0.59 \mathrm{~A} \pm 0.22$ & $28.84 \mathrm{~A} \pm 18.00$ \\
\cline { 2 - 6 } & 2014 & $6.35 \mathrm{a} \pm 3.20$ & $52.2 \mathrm{a} \pm 4.5$ & $3.31 \mathrm{a} \pm 1.45$ & $218.46 \mathrm{~b} \pm 52.63$ \\
& 2015 & $8.82 \mathrm{~b} \pm 4.62$ & $63.8 \mathrm{~b} \pm 7.1$ & $5.68 \mathrm{~b} \pm 1.97$ & $159.04 \mathrm{a} \pm 35.41$ \\
\hline
\end{tabular}

During sunny days, the dehiscence of anthers started 2-3 hours after flower opening. The number of anthers in double flowers of $P$. serrulata 'Kanzan' was 3 times lower than in $P$. serrulata 'Amanogawa'. Therefore, the pollen presentation period in $P$. serrulata 'Kanzan' flowers was very short, approx. 7-9 hours. In the flowers of $P$. serrulata 'Amanogawa' (with mean $=18.2$ anthers perflower), pollen resentation was extended to 2 days.

Significant cultivar effect $\left(F_{1,14}=4.067\right.$, $p=0.042)$ and year effect $\left(F_{1,14}=9.808, p=0.046\right)$ were found for the amount of pollen produced per flower. The mass of pollen produced in the flowers of $P$. serrulata 'Kanzan' was approx. 50\% lower than in P. serrulata 'Amanogawa' (Tab. 2). The total pollen yield varied between the cultivars. A single tree of $P$. serrulata 'Amanogawa' produced 2.5 times more pollen than a single tree of $P$. serrulata 'Kanzan'.

\section{Attractiveness to insect visitors}

The flowers of $P$. serrulata 'Kanzan' were not attractive to insect visitors. Insects foraged the flowers only sporadically. In total, 31 insect individuals were recorded on the flowers of $P$. serrulata 'Kanzan'. More insects (178) foraged the flowers of $P$. serrulata 'Amanogawa'. Among the insect visitors, the highest recorded proportion was that of Apis mellifera (Fig. 2).

\section{DISCUSSION}

In SE Poland, the ornamental P. serrulata 'Kanzan' and $P$. serrulata 'Amanogawa' flower in April/ May. Similarly, spring blossom on these trees was reported also in other parts of Europe and the USA (Chung et al., 2011; Ninić-Todorović et al., 2012).

In this study, a year-to-year disparity in the flowering period was observed. Over the last decade, significant shifts in plant phenology (of spring trees in particular) have been recorded (Kasprzyk, 2016). The shifts are explained to be a response to the climate change (Menzel et al., 2006). In particular, Prunus species are sensitive to air temperatures, which impact their phenology (Miller-Rushing et al., 2007), and Prunus trees are recognized as effective indicators of weather

Table 2. Number of anthers per flower, mass of pollen produced in anthers and flowers, and the total mass of pollen per tree in two cultivars of Prunus serrulata in the years 2014-2015 in Lublin (SE Poland). Means \pm SD (standard deviation) are given. Means followed by the same lower-case letter are not significantly different between years within cultivars, and values followed by the same capital letter are not significantly different between cultivars, at $p=0.05$ based on Tukey's HSD test

\begin{tabular}{lccccc}
\hline Cultivar & Year & $\begin{array}{c}\text { Number of anthers } \\
\text { per flower }\end{array}$ & $\begin{array}{c}\text { Mass of pollen } \\
\text { per 100 anthers } \\
(\mathrm{mg})\end{array}$ & $\begin{array}{c}\text { Mass of pollen } \\
\text { per flower } \\
(\mathrm{mg})\end{array}$ & $\begin{array}{c}\text { Mass of pollen } \\
\text { per tree } \\
(\mathrm{g})\end{array}$ \\
\hline \multirow{3}{*}{ Kanzan } & 2014 & $7.50 \mathrm{~b} \pm 3.21$ & $1.53 \mathrm{a} \pm 0.82$ & $0.11 \mathrm{~b} \pm 0.90$ & $6.93 \mathrm{~b} \pm 3.24$ \\
& 2015 & $3.20 \mathrm{a} \pm 1.12$ & $1.25 \mathrm{a} \pm 0.25$ & $0.04 \mathrm{a} \pm 0.02$ & $0.70 \mathrm{a} \pm 0.48$ \\
\hline \multirow{3}{*}{ Amanogawa } & mean & $5.35 \mathrm{~A} \pm 1.62$ & $1.39 \mathrm{~B} \pm 0.51$ & $0.08 \mathrm{~A} \pm 0.06$ & $3.82 \mathrm{~A} \pm 1.09$ \\
\cline { 2 - 6 } & 2014 & $24.60 \mathrm{~b} \pm 5.47$ & $1.10 \mathrm{~b} \pm 0.34$ & $0.27 \mathrm{~b} \pm 0.14$ & $17.82 \mathrm{~b} \pm 4.32$ \\
& 2015 & $11.80 \mathrm{a} \pm 4.32$ & $0.61 \mathrm{a} \pm 0.28$ & $0.07 \mathrm{a} \pm 0.05$ & $1.96 \mathrm{a} \pm 1.25$ \\
\hline
\end{tabular}




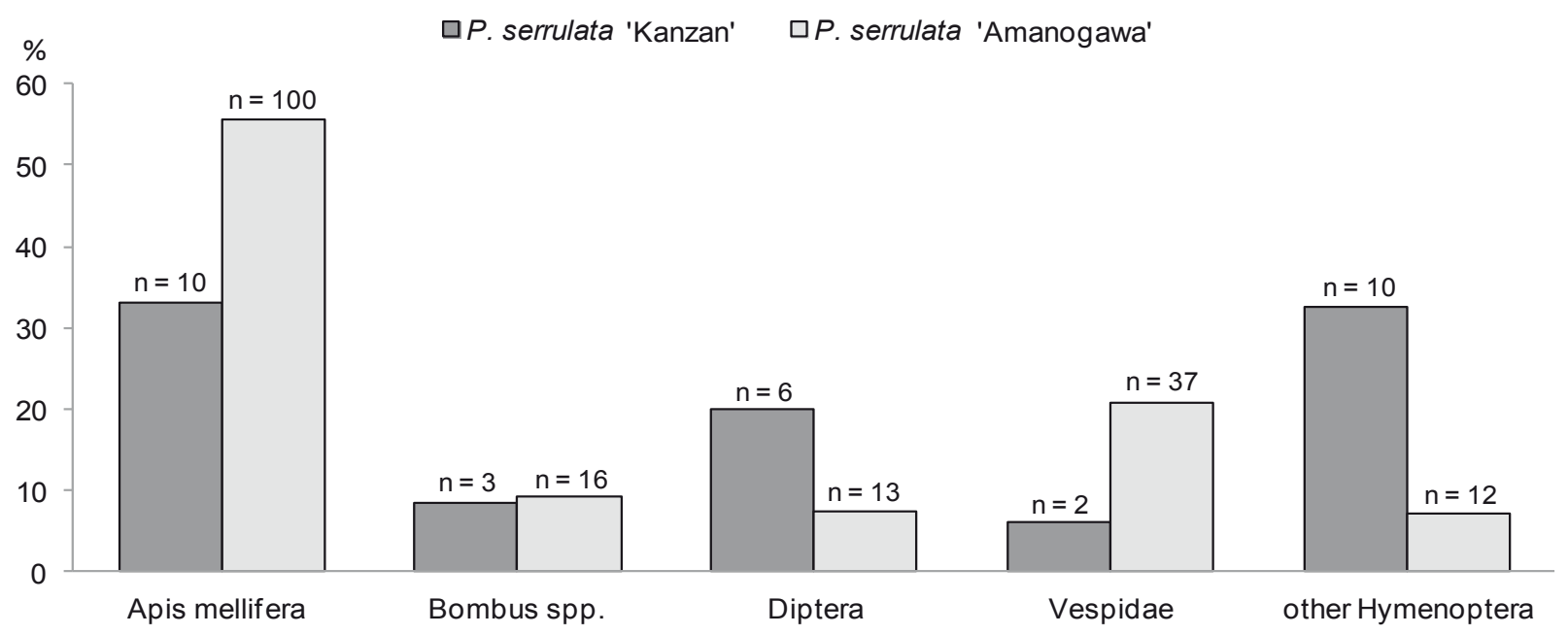

Figure 2. Percentage participation of insect visitors in two P. serrulata cultivars. Mean values from 2014 and 2015 are given; $\mathrm{n}=$ number of recorded insect individuals

conditions or even climate change affecting the tree flowering period (Primack et al., 2009).

$P$. serrulata 'Kanzan' and $P$. serrulata 'Amanogawa' are characterized by a mass floral display (Kato et al., 2012). However, the present study indicated that the number of developed flowers can be diminished, as a considerable decline in the number of flowers produced was documented every two years. Flowering is a complex process and can be affected by various environmental factors. In Prunus species, flowering may be limited by drops in winter temperatures and/or by early spring frost damage to buds (Gunes, 2006; Chung et al., 2011).

In this study, the significant disparities in nectar and sugar production were noted between the cultivars. The variability in the nectar/ sugar amount produced in the flowers had been previously reported in many studies and related to the differences between species, cultivars, or even among individual flowers (Denisow et al., 2014a; Bożek et al., 2015; Strzałkowska-Abramek et al., 2018). P. serrulata 'Kanzan' and P. serrulata 'Amanogawa' differed in flower types, which, no doubt, impacted the quantity of the floral reward offered. The semi-double flowers of $P$. serrulata 'Amanogawa' produced approximately three times more nectar compared to the double flowers of $P$. serrulata 'Kanzan'. It is accepted that flower morphology (corolla width/depth, flower size) as well as plant physiology can affect reward quantity (e.g. Nicolson and Thornburg, 2007; Denisow and Strzałkowska-Abramek, 2013). In particular, the species/cultivars with double flowers are recognized as poor nectar-yielding plants (Garbuzov and Ratnieks, 2014). According to Farkas and Zajácz
(2007), nectar/sugar production is lower in hybrids/ cultivars than in homogenous species. For example, certain cultivars of $P$. domestica secrete only tiny amounts of nectar (Horváth and Orosz-Kovács, 2004).

For each cultivar, differences in nectar production and nectar sugar concentrations were found between the growing seasons. Nectar production is dependent on diverse factors, e.g. temperature, relative humidity, light, or $\mathrm{CO}_{2}$ concentration (Petanidou and Smets, 1996; Jachuła et al., 2018b). Environmental factors have been reported to influence nectar/sugar production in many plant species, including trees and shrubs (Gupta et al., 1990; Stawiarz and Wróblewska, 2014).

In this study, pollen production per flower and per tree differed between the cultivars. Pollen potential was twice as high in semi-double flowers. This is consistent with other studies, which indicate that pollen production per flower is mainly related to the number of anthers developed per flower (Denisow et al., 2013; Stawiarz and Wróblewska, 2013; Strzałkowska-Abramek et al., 2016a). Moreover, for each cultivar, differences were noted between the growing seasons. The disparity in pollen production between the growing seasons may be related to differences in weather conditions (Strzałkowska-Abramek et al., 2016a). In particular, in early spring/spring plants, air temperatures are reported to diminish the mass of pollen produced in the anthers (Denisow and Strzałkowska-Abramek, 2013; Denisow et al., 2014a).

The estimated average sugar yield (28.8 g per tree) and pollen yield (3.82 g per tree), indicate that $P$. serrulata 'Kanzan' should be regarded as a poor 
forage-yielding plant. When arranging bee-friendly habitats, the cultivar should not be taken into consideration but replaced with the better sugarand pollen-yielding $P$. serrulata 'Amanogawa' or other forage species suitable for urban areas. For example, Caragana arborescens (Fabaceae) can produce $49.7 \mathrm{~g}$ of sugar and $9.7 \mathrm{~g}$ of pollen per shrub, on average, and is eagerly visited by honey bees and bumble bees (Stawiarz and Wróblewska, 2014).

\section{CONCLUSIONS}

For the selection of forage species that are suitable for bee pastures, the recognition of floral reward quantity and the determination of attractiveness to pollinating insects is necessary. $P$. serrulata 'Kanzan' offered only tiny amounts of nectar sugars and pollen, and received insect visits sporadically. Although P. serrulata 'Amanogawa' yielded approx. 6 times more sugars and 2.5 times more pollen than $P$. serrulata 'Kanzan', the species was not very attractive to pollinating insects either. Although P. serrulata 'Kanzan' and $P$. serrulata 'Amanogawa' are recommended for use in urban gardens and as street trees for ornamental arrangements, the trees should be excluded if pollinator-friendly habitats are arranged.

\section{FUNDING}

This research was supported financially by the Ministry of Science and Higher Education of Poland (project $\mathrm{OKB} / \mathrm{DS} / 2$ ) as part of statutory activities of the Department of Botany, University of Life Sciences in Lublin.

\section{AUTHOR CONTRIBUTIONS}

M.S.A. - designed the experiment, carried out field and laboratory experiments, performed statistical analyses and wrote the manuscript.

\section{CONFLICT OF INTEREST}

The author declares no conflict of interest.

\section{REFERENCES}

Abou-ShaARA H.F., 2014. The foraging behaviour of honey bees, Apis mellifera: A review. Vet. Med. (Praha) 59, 1-10.

Alaux C., Ducloz F., Crauser D., Le Conte Y., 2010. Diet effects on honeybee immunocompetence. Biol. Lett. 6, 562-565.

Antoń S., Denisow B., 2014. Nectar production and carbohydrate composition across floral sexual phases:
Contrasting patterns in two protandrous Aconitum species (Delphinieae, Ranunculaceae). Flora 209(9), 464-470.

Antoń S., Denisow B., 2018. Floral phenology and pollen production in the five nocturnal Oenothera species (Onagraceae). Acta Agrobot. 71: 1738, 1-12.

Antoń S., Komoń-Janczara E., Denisow B., 2017. Floral nectary, nectar production dynamics and chemical composition in five nocturnal Oenothera species (Onagraceae) in relation to floral visitors. Planta 246, 1051-1067.

Bożek M., Strzalkowska-Abramek M., Denisow B., 2015. Nectar and pollen production and insect visitation on ornamentals from the genus Hosta Tratt. (Asparagaceae). J. Apic. Sci. 59, 115-125.

Brodschneider R., Crailsheim K., 2010. Nutrition and health in honey bees. Apidologie 41, 278-294.

Chung U., Mack L., Yun J.I., Kim S.H. 2011. Predicting the timing of cherry blossoms in Washington, DC and mid-Atlantic states in response to climate change. PLoS One 6: e27439.

Denisow B., Antoń S., Szymczak G., 2013. The flowering, pollen production, and insect visitors in the ornamental shrub Potentilla fruticosa L. (Rosaceae). J. Apic. Sci. 57, 95-106.

Denisow B., Strzalkowska-Abramek M., 2013. Characteristics of blooming and pollen in flowers of two Syringa species (f. Oleaceae). Acta Agrobot. 66, 65-72.

Denisow B., Strzalkowska-Abramek M., Bożek M., JEŻAK A., 2014a. Early spring nectar and pollen and insect visitor behavior in two Corydalis species (Papaveraceae). J. Apic. Sci. 58, 93-102.

Denisow B., Strzalkowska-AbrameK M., BożeK M., JEŻAK A., 2014b. Ornamental representatives of the genus Centaurea L. as a pollen source for bee friendly gardens. J. Apic. Sci. 58, 49-58.

Denisow B., Strzalkowska-AbrameK M., PogroSZEWSKa E., LASKOWSKa H., 2016. The effect of Pentakeep $^{\circledR}-\mathrm{V}$ application on flower traits and nectar production in Hosta Tratt. 'Krossa Regal'. Acta Sci. Pol., Hortorum Cultus 15, 27-39.

Di Pasquale G., Salignon M., Le Conte Y., Belzunces L.P., Decourtye A., Kretzschmar A., et al., 2013. Influence of pollen nutrition on honey bee health: do pollen quality and diversity matter? PLoS One 8: e72016.

FARKAS Á., ZAJÁcZ E., 2007. Nectar production for the Hungarian honey industry. Eur. J. Plant Sci. Biotechnol. 1, 125-151.

FILIPIAK M., 2018. A better understanding of bee nutritional ecology is needed to optimize conservation strategies for wild bees - the application of ecological stoichiometry. Insects 9(3): 85.

Filipiak M., Kuszewska K., Asselman M., Denisow B., Stawiarz E., Woyciechowski M., ET AL., 2017. Ecological stoichiometry of the honeybee: Pollen diversity and adequate species composition are 
needed to mitigate limitations imposed on the growth and development of bees by pollen quality. PLoS One 12: e0183236.

Gallai N., Salles J.M., Settele J., Vaissière B.E., 2009. Economic valuation of the vulnerability of world agriculture confronted with pollinator decline. Ecol. Econ. 68, 810-821.

Garbuzov M., Ratnieks F.L.W., 2014. Quantifying variation among garden plants in attractiveness to bees and other flower-visiting insects. Funct. Ecol. 28, 364-374.

Goulson D., Nicholls E., Botías C., Rotheray E.L., 2015. Bee declines driven by combined stress from parasites, pesticides, and lack of flowers. Science 347: 1255957.

GunEs N.T., 2006. Frost hardiness of some Turkish apricot cultivars during the bloom period. HortScience 41, 310-312.

Gupta J.K., Reddy M.C.M., Kumar J., 1990. Pattern of nectar secretion in wild cherry, Prunus puddum Roxb, and the associated foraging behaviour of Apis cerana indica $\mathrm{F}$ and Apis mellifera L. Apidologie 21, 11-16.

Hicks D.M., Ouvrard P., Baldock K.C.R., Baude M., Goddard M.A., Kunin W.E., ET AL., 2016. Food for pollinators: quantifying the nectar and pollen resources of urban flower meadows. PLoS One 11: e0158117.

Horticulture statistics, 2017. Department for Environment Food and Rural Affairs. Issued May 2018. https://assets.publishing.service.gov.uk/govern ment/uploads/system/uploads/attachment_data/ file/712016/hort-report-31may18.pdf. Accessed 03 December 2018.

Horváth A., Orosz-Kovács Z.S., 2004. Individual variability of nectar secretion in the flowers of plum cv. 'Reine-Claude d'Althann'. Acta Hortic. 636, 357 363.

Jachula J., Denisow B., Wrzesień M., 2018 a. Validation of floral food resources for pollinators in agricultural landscape in SE Poland. J. Sci. Food Agric. 98, 2672-2680.

JaChula J., Konarska A., Denisow B., 2018 b. Micromorphological and histochemical attributes of flowers and floral reward in Linaria vulgaris (Plantaginaceae). Protoplasma 1-14.

Jachula J., Wrzesień M., StrZalkowska-Abramek M., Denisow B., 2018c. The impact of spatiotemporal changes in flora attributes and pollen availability on insect visitors in Lamiaceae species. Acta Bot. Croat. 77, 161-171.

KASPRZYK I., 2016. The variation of the onset of Betula pendula (Roth.) flowering in Rzeszów, SE Poland: fluctuation or trend? Acta Agrobot. 69: 1667, 1-10.

Kato S., Matsumoto A., Yoshimura K., Katsuki T., Iwamoto K., Tsuda Y., ET AL., 2012. Clone identification in Japanese flowering cherry (Prunus subgenus Cerasus) cultivars using nuclear SSR markers. Breed. Sci. 62, 248-255.

Matteson K.C., LANGellotto G.A., 2011. Small scale additions of native plants fail to increase beneficial insect richness in urban gardens. Insect Conserv. Diver. 4, 89-98.

Menzel A., Sparks T.H., Estrella N., Koch E., Aasa A., Ahas R., ET AL., 2006. European phenological response to climate change matches the warming pattern. Global Change Biol. 12, 1969-1976.

Miller-Rushing A.J., Katsuki T., Primack R.B., IshiI Y., LeE S.D., Higuchi H., 2007. Impact of global warming on a group of related species and their hybrids: cherry tree (Rosaceae) flowering at Mt. Takao, Japan. Amer. J. Bot. 94(9), 1470-1478.

NePi M., Grasso D.A., Mancuso S., 2018. Nectar in plant-insect mutualistic relationships: from food reward to partner manipulation. Front. Plant Sci. 9: 1063.

Nicolson S.W., Thornburg R.W., 2007. Nectar chemistry. In: Nectaries and Nectar. S.W. Nicolson, M. Nepi and E. Pacini (Eds), Springer, Dordrecht, 215-264.

Ninić-Todorović J., Ognjanov V., Čukanović J., Kurjakov A., Mladenović E., LuUbojević M., ET AL., 2012. Ornamental Prunus taxons (Prunus serrulata Lindl. and Prunus fruticosa Pall. 'Globosa') on Novi Sad green areas. Proc. $2^{\text {nd }}$ Int. Conf. "Ecology of Urban Areas 2012”, 12 October, Kaštel - Ečka, Zrenjanin, Hunting Manor, Serbia, 386.

Petanidou T., Smets E., 1996. Does temperature stress induce nectar secretion in Mediterranean plants? New Phytol. 133, 513-518.

Primack R.B., Higuchi H., Miller-Rushing A.J., 2009. The impact of climate change on cherry trees and other species in Japan. Biol. Conserv. 142, 19431949.

Rhodes C.J., 2018. Pollinator decline - An ecological calamity in the making? Sci. Prog. 101, 121-160.

Rysiak A., CzarnecKa B., 2018. The urban heat island and the features of the flora in the Lublin City area, SE Poland. Acta Agrobot. 71, 1736.

Somme L., Moquet L., Quinet M., Vanderplanck M., Michez D., Lognay G., ET AL., 2016. Food in a row: urban trees offer valuable floral resources to pollinating insects. Urban Ecosyst. 19, 1149-1161.

Stawiarz E., WróBlewsKa A., 2013. Flowering dynamics and pollen production of Laburnum anagyroides Med. under the conditions of SouthEastern Poland. J. Apic. Sci. 57, 103-115.

Stawiarz E., WróblewsKa A., 2014. Flowering of Siberian peashrub (Caragana arborescens Lam.) and its forage value to pollinating insects. Acta Agrobot. 67, 13-20.

Strzalkowska-Abramek M., Jachula J., Dmitruk M., Pogroszewska E. 2016a. Flowering phenology and pollen production of three early spring Pulsatilla species. Acta Sci. Pol., Hortorum Cultus 15, 333-346. 
StrZaŁkowsKa-AbrameK M., TymoszuK K., JaChuŁa J., BożEK M. 2016b. Nectar and pollen production in Arabis procurrens Waldst. \& Kit. and Iberis sempervirens L. (Brassicaceae). Acta Agrobot. 69(1): 1656, 1-10.

StrZaŁKOWSKa-AbrameK M., JaChUŁa J., WrZeSIEŃ M., Bożek M., DąBrowska A., Denisow B., 2018. Nectar production in several Campanula species (Campanulaceae). Acta Sci. Pol., Hortorum Cultus 17, 127-136.

Vanbergen A.J., Garratt M.P., Vanbergen A.J., Baude M., Biesmeijer J.C., Britton N.F., et AL., 2013. Threats to an ecosystem service: Pressures on pollinators. Front. Ecol. Environ. 11, 251-259.
Wrzesień M., Denisow B., Mamchur Z., Chuba M., RESLER I., 2016a. Composition and structure of the flora in intra-urban railway areas. Acta Agrobot. 69(3):1666, 1-14.

Wrzesień M., JAChuŁa J., Denisow B., 2016b. Railway embankments - Refuge areas for food flora, and pollinators in agricultural landscape. J. Apic. Sci. 60, 97-110.

Ziaja M., Denisow B., Wrzesień M., WóJCiK T., 2018. Availability of food resources for pollinators in three types of lowland meadows. J. Apic. Res. 57, 467-478.

Received December 10, 2018; accepted March 8, 2019 